\title{
A Reconsideration of Purported Holocene Bison Bones from Northern Alaska
}

\author{
JEFFREY T. RASIC ${ }^{1}$ and PAUL E. MATHEUS ${ }^{2}$
}

(Received 7 December 2006; accepted in revised form 1 May 2007)

\begin{abstract}
While bison were the most abundant large mammals in Eastern Beringia for most of the last 100000 years, their range declined drastically at the end of the Pleistocene and through the Holocene. Research into the nature of Holocene human interactions with bison suffers from scarcity of faunal remains from most archaeological sites and poor chronological control of paleontological specimens over broad areas of Eastern Beringia. We examined the dating, context, and identification of purported bison bones spatially associated with two late prehistoric archaeological sites in northern Alaska to contribute to a better understanding of bison biogeography and the possible role of these large mammals in prehistoric economies. We confirmed the presence of two bison bones from the 17th century Kangiguksuk archaeological site (49-XBM-012) in northwestern Alaska, but radiocarbon dates older than $30000{ }^{14} \mathrm{C}$ years BP for both bones demonstrate that those bison were not hunted by the site occupants. From the Lakeside site (49-KIR-275) in the central Brooks Range, a bone reported to be bison and dated to about $2400{ }^{14} \mathrm{C}$ years BP was shown through DNA sequencing to be moose (Alces alces). We point to a large set of dated bison specimens from Alaska's Arctic Slope that suggests bison were locally extinct in north-central and northwestern Alaska by the beginning of the Holocene and were subsequently unavailable to human hunters in that region.
\end{abstract}

Key words: Alaska, Beringia, bison, Bison priscus, moose, archaeology, radiocarbon dating, Holocene, Pleistocene

RÉSUMÉ. Bien que le bison était le gros mammifère le plus abondant de la Béringie de l'Est pendant la plus grande partie des 100000 dernières années, sa répartition a diminué considérablement à la fin du pléistocène et pendant l'holocène. Puisque la plupart des sites archéologiques présentent peu de restes d' animaux et que le contrôle chronologique des spécimens paléontologiques sur de grandes régions de la Béringie de l'Est laisse à désirer, cela rend difficiles les recherches portant sur la nature des interactions humaines avec le bison pendant la période de l'holocène. Nous avons examiné la datation, le contexte et l'identification des soidisant os de bison géographiquement rattachés à deux anciens sites archéologiques préhistoriques du nord de l'Alaska afin de pouvoir mieux comprendre la biogéographie du bison de même que le rôle possible de ce gros mammifère au sein des économies préhistoriques. Nous avons confirmé la présence de deux os de bison provenant du site archéologique Kangiguksuk du XVII ${ }^{\text {siècle }}$ (49-XBM-012) dans le nord-ouest de l'Alaska, mais d'après les dates déterminées par la méthode du carbone 14 remontant à plus de $30000{ }^{14} \mathrm{C}$ années BP pour les deux os, ces bisons n'ont pas été chassés par les occupants du site. Au site Lakeside (49-KIR275) de la chaîne centrale Brooks, un os qui était censé appartenir à un bison dont la datation était d'environ $2400{ }^{14} \mathrm{C}$ années BP était en fait celui d'un original, ce qui a été déterminé grâce au séquençage de l'ADN (Alces alces). Nous faisons mention d'un grand ensemble de spécimens de bisons datés et provenant du talus de l'Arctique de l'Alaska. Ces spécimens laissent supposer que les bisons avaient disparu du centre-nord et du nord-ouest de l'Alaska vers le début de l'holocène et par conséquent, ils n'étaient pas à la portée des chasseurs humains de cette région.

Mots clés : Alaska, Béringie, bison, Bison priscus, orignal, archéologie, datation déterminée par la méthode du carbone 14, holocène, pléistocène

Traduit pour la revue Arctic par Nicole Giguère.

\section{INTRODUCTION}

Bison (Bison priscus) were the most abundant large mammals in Eastern Beringia (unglaciated Alaska, Yukon and parts of adjacent Northwest Territories) from at least 100000 until nearly 10000 years ago. In central Alaska and the Yukon, approximately half of all bones recovered from late Pleistocene sediments are from bison (Guthrie, 1968, 1990), and in northern Alaska (defined here as the area encompassing the Brooks Range mountains and North Slope), bison bones comprise about one-quarter to onethird of the finds (Matheus et al., 2003). The decline of bison across Eastern Beringia at the end of the Pleistocene occurred against a backdrop of a substantial ecological reorganization (Shapiro et al., 2004; Guthrie, 2006). However, the tempo, absolute timing, and perhaps the causes of these changes differ among subregions and remain key research questions. Human predation does not seem to be

\footnotetext{
${ }^{1}$ National Park Service, Gates of the Arctic National Park and Preserve/Yukon-Charley Rivers National Preserve, 4175 Geist Road, Fairbanks, Alaska 99701, USA; Jeff_Rasic@nps.gov

${ }^{2}$ Alaska Quaternary Center, University of Alaska Fairbanks, Box 755940, Fairbanks, Alaska 99775-5940, USA

(C) The Arctic Institute of North America
} 
the driving force behind the bison decline, since genetic studies indicate decreasing populations of Beringian bison beginning about $37000{ }^{14} \mathrm{C}$ years $\mathrm{BP}$, well before the widespread appearance of humans in the region after about $12000{ }^{14} \mathrm{C}$ years BP (Shapiro et al., 2004; Bever, 2006). The early date of this decline does not, however, preclude significant interactions between human populations and bison. In fact, on a global scale, wherever humans and bison have coexisted, bison have been a resource of central importance and one that strongly influenced the basic structure of human economies, mobility, and social life (Bamforth, 1988:5; Frison, 1991). Given the abundance of bison in Beringia, it would be surprising indeed if they had not been an important subsistence resource in the region, and if the interactions between people and bison had not been significant (Kunz et al., 1999). This is a difficult problem to investigate, however, because of the scarcity of faunal remains from most archaeological sites and the poor chronological control of paleontological specimens over broad areas.

The Holocene is a particularly interesting interval for which to examine changes in bison distribution since there is clear and widespread archaeological evidence of human occupation during this time, and it is also the time when the once ubiquitous bison became extinct across most of Eastern Beringia and came to occupy their current drastically reduced range. One recent study by Stephenson et al. (2001) has made a substantial contribution to the understanding of this topic. The authors draw upon Athapaskan oral history, combined with evidence from a set of 44 radiocarbon dated bison bones, to demonstrate the persistence of bison as recently as a few hundred years ago. Their data suggest that the core area for Holocene bison was the upper Yukon and Tanana River basins of east-central Alaska and Yukon Territory (Fig. 1). However, they also report a single occurrence of bison north of the Brooks Range at the Lakeside site (which we re-examine in this paper).

Despite these and other recent data (Guthrie, 2006), the picture of Holocene bison distribution is still rather coarsegrained. For spans of millennia, even the presence or absence of bison in large subregions of Eastern Beringiafor example, the Brooks Range and southwestern Alaskaremains unknown. The interactions between people and bison are even less well known since most dated bison are from non-cultural contexts. Bison remains have been identified in only five Holocene archaeological components in Alaska (Stephenson et al., 2001) among more than 20000 recorded prehistoric sites. In comparison, a cursory review of these site records in the Alaska Heritage Resources Survey database shows that at least 171 archaeological sites contain caribou elements. It is puzzling that evidence of prehistoric bison hunting is not more common, given the abundance of bison in certain times and places within Eastern Beringia and the fact that these large-bodied and gregarious animals would have been highly ranked prey.

One explanation for bison scarcity in archaeological contexts is that it reflects sampling or taphonomic factors

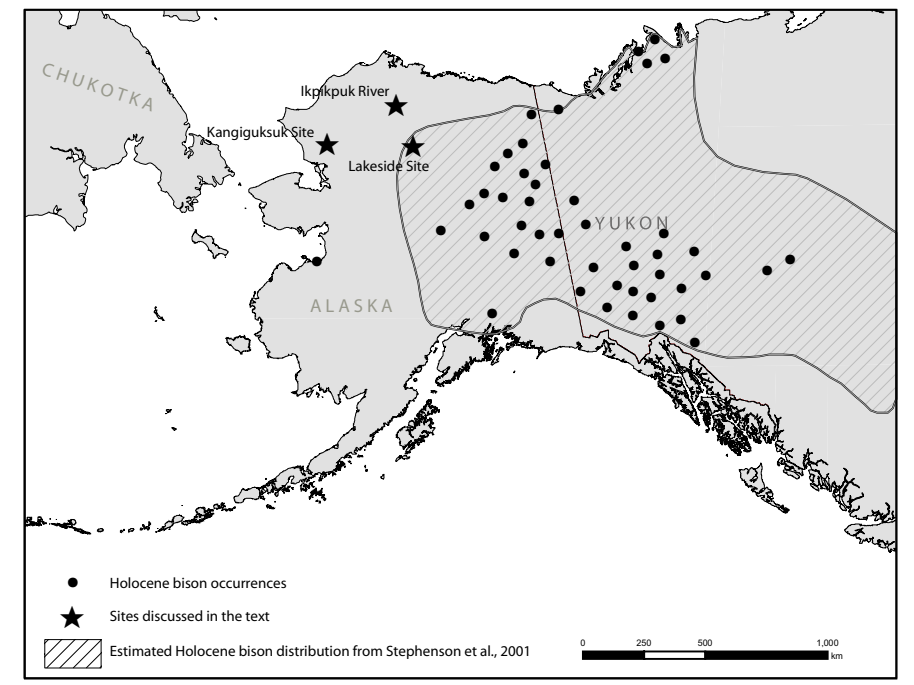

FIG. 1. Map of Eastern Beringia (Alaska, Yukon Territory, and parts of adjacent Northwest Territories) showing the Kangiguksuk, Lakeside, and Ikpikpuk River sites. The shaded area represents the range of Holocene bison as estimated by Stephenson et al., 2001.

such as a bias toward preservation of younger archaeological sites; under-representation of certain kinds of sites in which faunal remains are most abundant, such as kill locations and residential camps; inaccurate specimen identification; and incomplete site reporting. From this perspective, even a single dated bison can add to our knowledge, and more so if derived from a clearly understood geological or archaeological context. This paper contributes to the picture of bison biogeography in Beringia by presenting new information on three purported bison bones spatially associated with two late prehistoric archaeological sites in northern Alaska: the Kangiguksuk (49-XBM-012) and Lakeside (49-KIR-275) sites. While the contexts of these finds suggest that they may date to the Holocene, we set out to clarify questions about their identification as bison, their absolute age, and the precise nature of their associations with human activities.

\section{THE KANGIGUKSUK SITE}

The Kangiguksuk archaeological site, located on the middle Noatak River in northwestern Alaska, was excavated by Edwin S. Hall Jr. in 1963 and 1965 (Hall, 1966, 1971). It consists of a late prehistoric Iñupiat semi-subterranean house feature dated by dendrochronology and artifact typology to the 16th century AD. The site yielded a well-preserved faunal assemblage with a range of taxa typical for the region and time period: caribou (Rangifer tarandus), sheep (Ovis dalli), hare (Lepus sp.), and ptarmigan (Lagopus sp.). It also contained a few anomalous finds that included mammoth and bison. Hall (1971) ascribed the bison and mammoth to the Pleistocene and apparently concluded that the bones were collected as fossils by the site's occupants. However, in light of recent studies that have demonstrated the survival of bison into the late 

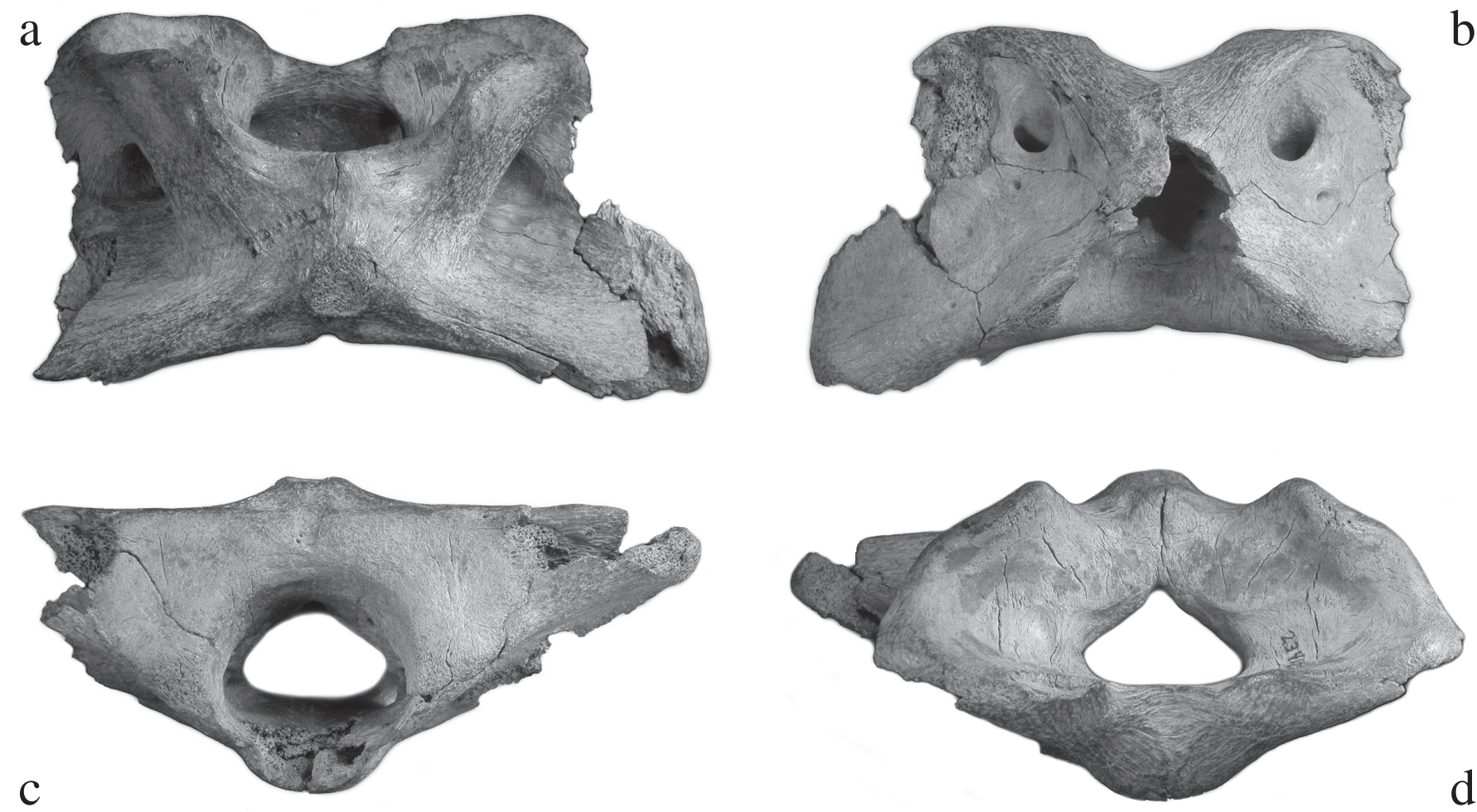

FIG. 2. Bison (Bison sp.) atlas from the Kangiguksuk site, catalog number YPM 234122, showing (a) ventral, (b) dorsal, (c) caudal, and (d) cranial views.

Holocene in parts of Alaska (Stephenson et al., 2001), and given the complete absence of dated bison remains from the Noatak River basin to provide background, it is possible that bison were part of the late prehistoric-age fauna represented at Kangiguksuk.

Hall notes two bison specimens in his 1971 site monograph, which are described as a "horn" and "phalange" but provides little contextual information from which to infer how they came to be deposited at the site. He does discuss in general terms the presence of Pleistocene bones in alluvial contexts along the Noatak River and their occasional use as raw materials for implement manufacture (Hall, 1971:56). It is clear that Hall did not consider the bison bones to represent food remains since he does not mention bison in the course of his detailed discussion of the diet and food procurement activities engaged in by the site's residents.

Another possible explanation for the presence of bison bones in this apparently late context is that, rather than being actively collected by people, the bones were deposited by natural processes at a location later chosen as an Iñupiat dwelling site, and were subsequently exposed when either the site's occupants or Hall excavated the semi-subterranean house. Specific provenience for the bones is not described in Hall's publications, and it is unclear whether they derived from the late prehistoric-age deposits or were found below them. We were unable to obtain Hall's field notes, which might shed light on the geological context of the specimens.
To address some of the questions surrounding the Kangiguksuk bison bones, we examined two bones in the Yale Peabody Museum (YPM) that are documented as having been collected from the site. Although Hall reported the bison specimens as a phalanx and a horn core, the YPM collection contained an atlas and a horn core. We did not locate or find additional reference to a bison phalanx in the YPM catalog. It is difficult to imagine confusion between an atlas and phalanx, and we posit that there were actually three bison bones recovered from the site- the horn core, a missing phalanx, and a previously unreported atlas. The YPM catalog information, specimen label, and the general appearance of the atlas (i.e., degree of weathering, damage patterns, and adhering sediments) help confirm that both it and the horn core are from the Kangiguksuk site.

Both Kangiguksuk bone specimens are bison, judging by their anatomical landmarks. The first specimen (YPM 234122, Fig. 2) is a nearly complete atlas from a large individual. It lacks cut marks or signs of human modification, but exhibits considerable water transport damage in the form of abrasion, edge-rounding, and polishing. The second specimen (YPM 234149, Fig. 3) is a horn core from an adult female. Like the atlas, the horn core also has considerable water transport damage and lacks signs of human modification. The evidence of water transport damage is consistent with the bones having been re-deposited naturally at Kangiguksuk, or carried there by the site's residents who collected the bones from a secondary alluvial context. The condition of the bison bones contrasts 

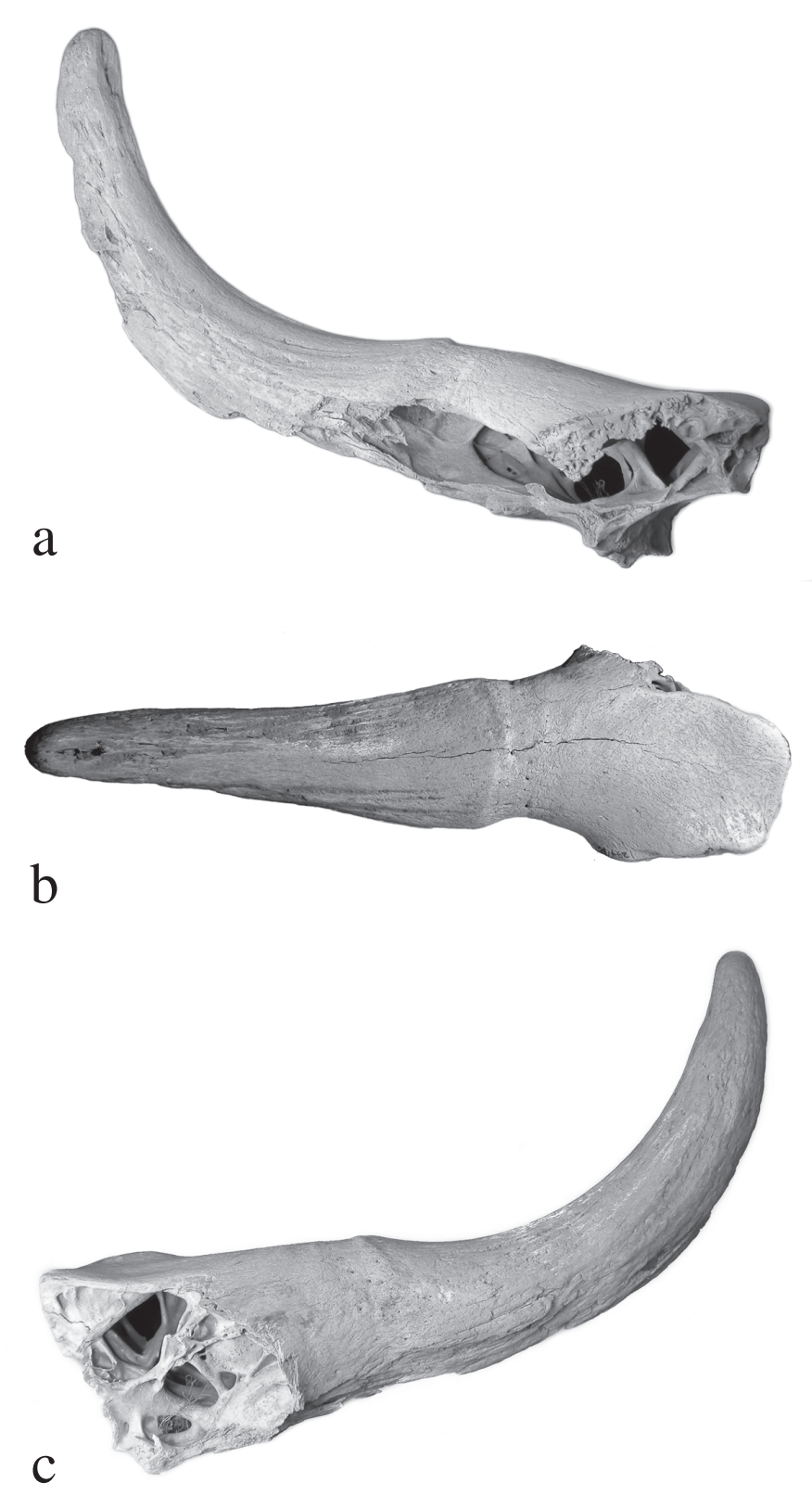

FIG. 3. A left bison (Bison sp.) horn core from the Kangiguksuk site, catalog number YPM 234149, showing (a) posterior, (b) superior, and (c) anterior views.

with other faunal remains at the site that are from unquestionable archaeological context. The archaeological bones are well preserved and unweathered, with no evidence of water transport damage.

To establish the age of the bones, we cut a small fragment (approximately $15 \times 10 \times 5 \mathrm{~mm}$, weighing $200-$ $300 \mathrm{mg}$ ) of each specimen from an area containing solid cortical bone. Collagen from these samples was extracted and purified at the University of Alaska Fairbanks using a modified Longin method (Stafford et al., 1988; Matheus, 1995). Collagen samples were well preserved, as indicated by their high collagen content, low $\mathrm{C}: \mathrm{N}$ ratios, white, needle-shaped (acicular) crystalline structure, and $\delta^{13} \mathrm{C}$ and $\delta^{15} \mathrm{~N}$ values that are typical of late Pleistocene bison in
Alaska (Table 1). Radiocarbon analyses of collagen aliquots were performed at the Lawrence Livermore National Laboratory's Center for Accelerator Mass Spectrometry (Table 1). Both bones date to more than $30000{ }^{14} \mathrm{C}$ years $\mathrm{BP}$, and it is clear that these particular bison did not persist into the Holocene, nor were they hunted by the 16thcentury residents of Kangiguksuk.

\section{THE LAKESIDE SITE}

Another Brooks Range bone that has been reported as bison (Stephenson et al., 2001; Saleeby, 2002) is the distal end of a metatarsal (GAAR 7846) that was collected from the vicinity of the Lakeside archaeological site (49-KIR275) in 1991 (Fig. 4). The Lakeside site is located within a deflating dune field adjacent to the exposed bed of a drained lake on the east side of the Killik River within Gates of the Arctic National Park and Preserve. The site consists of a $12 \times 6 \mathrm{~m}$ surface scatter of fire-cracked rock, stone tools, and flaking debris; a stone anvil; a hammer stone; and bones of large and small mammals (Spearman, 1991). An important fact regarding the distribution of artifacts and bone is that the suspected bison metatarsal fragment was located $15 \mathrm{~m}$ from the nearest edge of this artifact scatter.

Although definitive cultural materials at the Lakeside site have not been dated absolutely, the site contains a thick, stemmed chert arrow point (Fig. 5) of a type found in late prehistoric Iñupiat sites and consistently dated to after AD 900 in northern Alaska (Larsen and Rainey, 1948; Giddings, 1952; Ford, 1959:137; Stanford, 1976). The stone tools and other bones within the artifact cluster appear to represent a single occupation episode, judging by the relatively small size of the scatter and the homogeneous character of the lithic raw materials, which are entirely composed of glassy black chert. We interpret the archaeological site, then, to represent a single-component late prehistoric Iñupiat occupation dated to between $\mathrm{AD}$ 900 and 1800.

In 1998, one of us (Matheus) examined the metatarsal and from its morphology identified it as either moose or bison, but probably the latter. On the basis of this identification, the bone was subsequently reported as bison in the literature (Stephenson et al., 2001; Saleeby, 2002), but when it was later included in a study of bison paleogenetics (Shapiro et al., 2004), mitochondrial DNA sequences amplified from the specimen showed that it was, in fact, moose (Alces alces) (Beth Shapiro, pers. comm. 2001).

AMS radiocarbon dates on collagen have previously been generated from this moose metatarsal. All overlap at the two-sigma range and yield an average age of $2430{ }^{14} \mathrm{C}$ years BP (Table 2). Given the discrepancy of at least 1200 years between the statistically probable ( 2 sigma) age of the moose metatarsal and the maximum estimated age of the site, and the fact that the bone was collected at a distance from the artifact scatter, it appears the bone is 
TABLE 1. Chemical and isotopic analyses of collagen extracted from bison bones from the Kangiguksuk Site, Alaska.

\begin{tabular}{|c|c|c|c|c|c|c|c|}
\hline Catalog No. & Lab ID & Description & $\mathrm{C}: \mathrm{N}$ ratio & $\%$ Collagen Yield ${ }^{1}$ & $\delta^{13} \mathrm{C}$ & $\delta^{15} \mathrm{~N}$ & ${ }^{14} \mathrm{C}$ Age BP \\
\hline YPM 234122 & CAMS-107316 & Bison sp. atlas & 3.14 & 19 & -20.4 & 5.0 & $30780 \pm 330$ \\
\hline YPM 234149 & CAMS-107317 & Bison $\mathrm{sp}$. horn core & 3.14 & 18 & -20.1 & 3.6 & $34820 \pm 460$ \\
\hline
\end{tabular}

${ }^{1}$ Collagen yield calculated as percentage of whole bone dry weight.

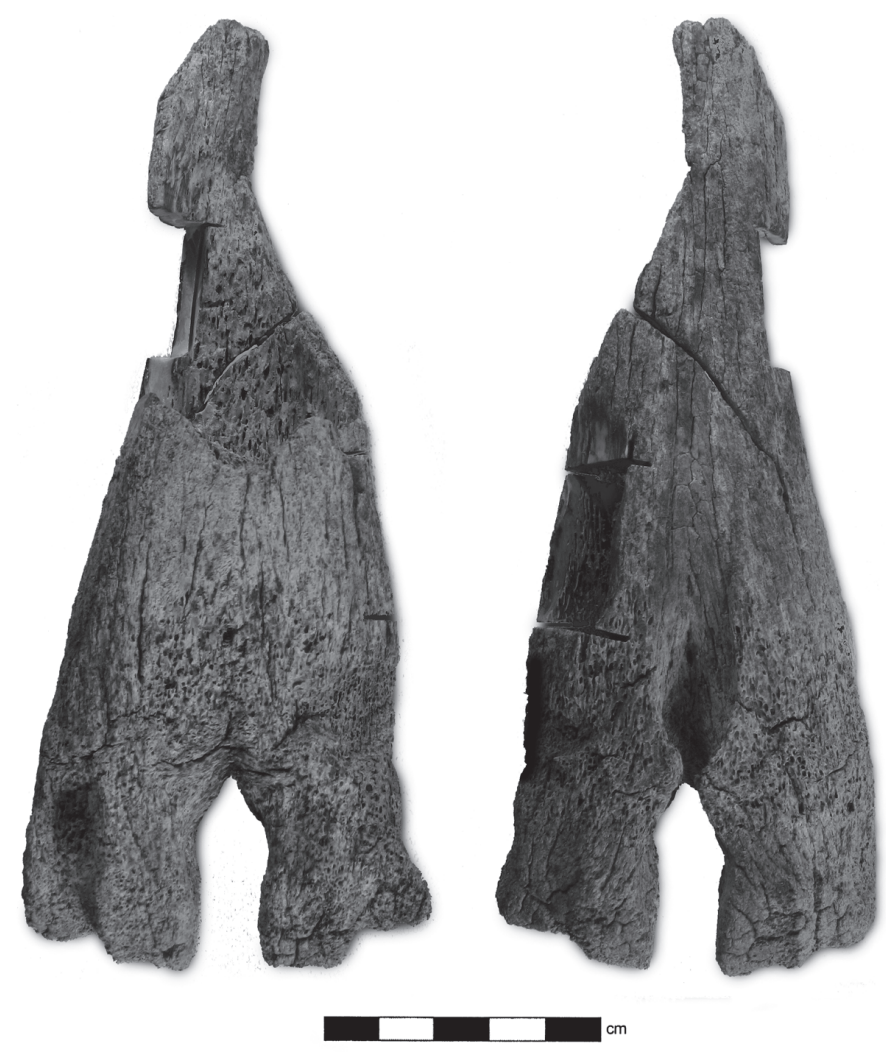

FIG. 4. Distal end of a moose (Alces alces) metatarsal from the Lakeside site, catalog number GAAR 7846, showing (a) posterior and (b) anterior views. Note the two rectangular notches on the lateral and medial margins, where samples were cut for DNA analysis and radiocarbon dating.

unassociated with the human occupation of the site. The bone lacks any direct evidence (such as cut marks, burning, or other purposeful modifications) to indicate an association with human activities. We interpret it to be naturally deposited and fortuitously proximate to the archaeological materials at the site. Isolated bone specimens such as this are not uncommon in the dry lake beds and dune blowouts found in the Killik River valley.

\section{DISCUSSION}

Although it is well established that bison persisted until recent times in parts of interior Alaska and adjacent Canada, there is currently no evidence for late (Holocene) survival of bison in other areas of Eastern Beringia, such as northern and southwestern Alaska. In this study, we re-examined three candidate Holocene bison fossils from northern Alaska and rejected all three. Reevaluation of the Lakeside
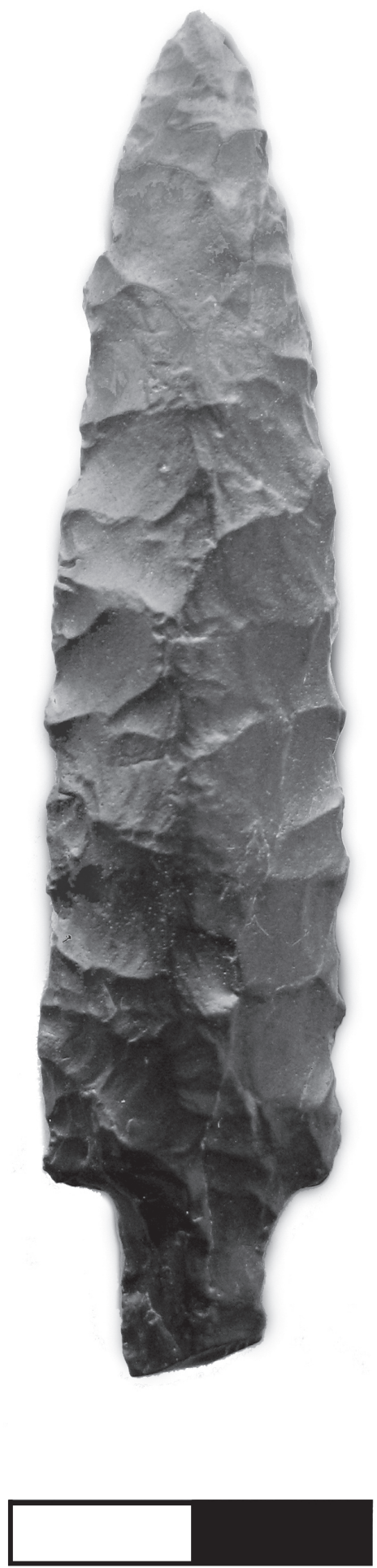

$\mathrm{cm}$

FIG. 5. Late prehistoric Iñupiat stemmed projectile point from the Lakeside site, catalog number GAAR 7511. 


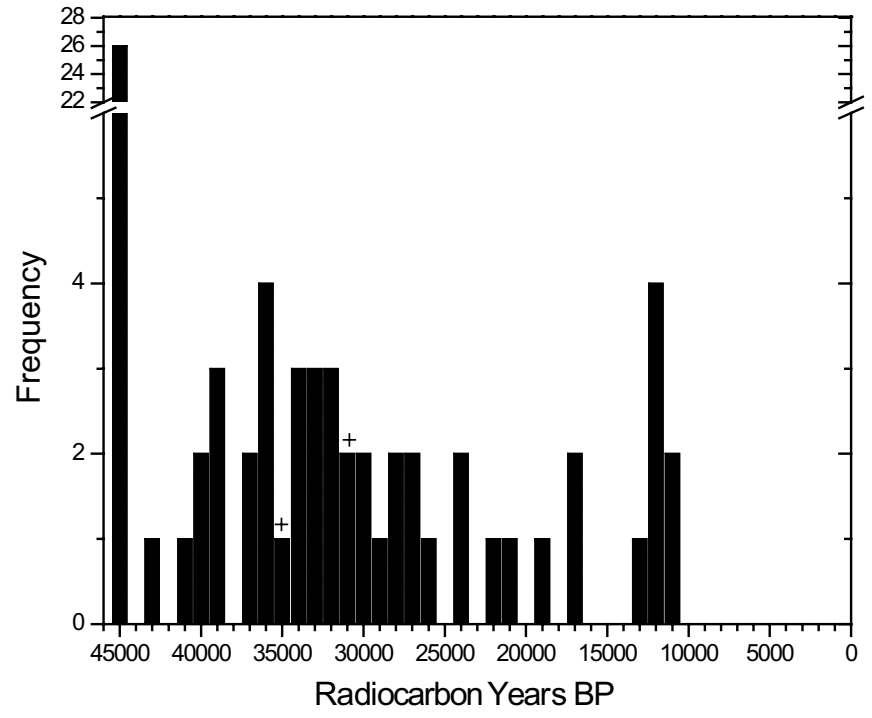

FIG. 6. Histogram of all known radiocarbon dates for Bison sp. collected in northern Alaska $(\mathrm{n}=73)$. Note that no dates are more recent than $10300 \mathrm{BP}$ and there is no other significant hiatus in the distribution of dates. Dates were grouped in 1000-year bins for graphing. Plus signs indicate the ages of the Kangiguksuk dates generated for this study. Compiled from data in Matheus et al., 2003, Shapiro et al., 2004, and this study.

site specimen reduces substantially (by some $350 \mathrm{~km}$ ) the previously reported northwestern distribution of Holoceneage bison in Alaska: it confines the known occurrence of bison to the forested interior of the Tanana and upper Yukon rivers and eastward into the Yukon and Northwest Territories.

We suggest that bison became extinct in northern Alaska during the Pleistocene-Holocene transition, probably around $10200-10000{ }^{14} \mathrm{C}$ years BP. This hypothesis is bolstered by an extensive North Slope radiocarbon data set generated by Matheus (2003) and Matheus et al. (2003), with additional data appended here. They collected nearly 3000 fossils of late Quaternary mammals from fluvial systems on the central North Slope of Alaska (particularly from the Ikpikpuk River, see Fig. 1) and radiocarbondated 320 of them, including 60 mammoth, 60 horse, 65 muskox, 60 caribou, and 71 bison fossils. Ages for bison ranged from more than 45000 to $10300{ }^{14} \mathrm{C}$ years $\mathrm{BP}$, with no statistically significant hiatuses (Fig. 6). Caribou and muskox bones dated to both the Holocene (23\% of caribou and $6 \%$ of the muskox) and the Pleistocene, which indicates that there was good opportunity to detect Holocene bison if they were present in the bone assemblage. After all, Holocene bison have been detected in the interior, where roughly the same number $(\sim 100)$ of radiocarbon dates has been generated. It also appears that the number of radiocarbon dates was sufficiently large to capture final occurrences of some extinct taxa. For example, the date for the youngest horse in the study $\left(12465 \pm 40{ }^{14} \mathrm{C}\right.$ years BP $)$ is close to the youngest date for that species anywhere in Eastern Beringia (see compilations of dates in Harington, 2003; Guthrie, 2006). Consequently, we conclude that the North Slope radiocarbon data set accurately (though perhaps not precisely) captures the time range of bison in that
TABLE 2. Radiocarbon dates on moose (Alces alces) metatarsal fragment (GAAR 7846) from the Lakeside Site.

\begin{tabular}{lccc}
\hline \hline Lab ID & Description & ${ }^{14} \mathrm{C}$ Age BP & ${ }^{13} \mathrm{C}$ \\
\hline Beta-130571 & moose metatarsal & $2330 \pm 50$ & -23.4 \\
CAMS-58093 & moose metatarsal & $2490 \pm 40$ & -20.8 \\
CAMS-58096 & moose metatarsal & $2460 \pm 40$ & -21.0 \\
\hline \hline
\end{tabular}

area: specifically, that they were present throughout the late Pleistocene but went extinct locally shortly after $10300{ }^{14} \mathrm{C}$ years BP.

A central question that remains is why bison disappeared from northern Alaska but persisted for several millennia in adjacent regions. We suggest the following ecological mechanisms for the extinction of northern bison at the end of the Pleistocene. Bison are grazing ruminants adapted to a diet of moderate-quality graminoids (moderate- to high-protein grasses and sedges), though high-quality woody browse can constitute an important component of the diet, at least seasonally (Guthrie, 1990). As a consequence, their evolution has been tied to the Holarctic expansion of cool grasslands-mainly steppes and open woodlands-during the Pleistocene. By the late Pleistocene, bison came to be the most abundant large mammals of the Mammoth Steppe in Beringia (Guthrie, 1990).

While northern Alaska was within this band of cool grasslands, the region likely provided less favorable bison habitat during the late Pleistocene than did interior Alaska and other parts of Beringia. In interior Alaska, bison constitute over $50 \%$ of the late Pleistocene large-mammal bone assemblage (Guthrie, 1968, 1990), and at some sites in the Klondike, Yukon, over $75 \%$ of recovered bones can be from bison (Matheus, unpubl. data). In contrast, bison comprise only about one-quarter to one-third of the assemblage from northern Alaska (Matheus, 2003). Bones of the horse, another grazer, are also relatively less common in the north. In contrast, caribou and muskox, two large herbivores adapted to foraging on tundra vegetation (i.e., mixed diets of forbs, graminoids, and shrubs), constitute a greater percentage of the late Pleistocene large-mammal community in northern Alaska than they do anywhere else in Beringia (Kunz et al., 1999; Matheus, 2003). These patterns in large-mammal bone assemblages therefore suggest that during the late Pleistocene, pockets of tundralike habitat were more prevalent and steppe vegetation less vast or of lower quality in northern Alaska than in interior Alaska (Kunz et al., 1999; Matheus, 2003).

Tundra ecosystems are a product of cold paludified conditions, a thin active layer, and a short growing season - conditions that support forbs and shrubs with conservative growth strategies over graminoids. The modern ecosystems of northern Alaska constitute a spectrum of wet to moist tundra, with occasional islands of well-drained uplands containing dry tundra. According to Mann et al. $(2001,2002)$, post-glacial paludification of northern Alaska lowlands began around $12500{ }^{14} \mathrm{C}$ years $\mathrm{BP}$, brought about 
by reduced continentality and a commensurate increase in effective moisture. This climatic transition is manifested in paleoecological records by rising lake levels, dune stabilization, partial melting of permafrost in lowland sites, increased alluviation and hillslope erosion, and accumulation of soil organics (peat). These conditions would have favored (and indeed reflect) the growth of tundra vegetation over more mesic and xeric graminoid-dominated vegetation that characterized the late glacial system prior to $12500{ }^{14} \mathrm{C}$ years BP (Anderson and Brubaker, 1994; Oswald et al., 1999).

Around $11000{ }^{14} \mathrm{C}$ years BP, northern Alaska briefly reverted to cooler and drier climatic conditions, coincident with the Younger Dryas stadial (Mann et al., 2002). Those conditions would have been favorable for the production of forage plants preferred by bison and may explain the last peak of bison dates in Figure 6. After the Younger Dryas (i.e., $\sim 10200{ }^{14} \mathrm{C}$ years BP), however, paludification and the spread of tundra systems resumed. Upland sites, which would have favored graminoid growth and functioned as habitat for bison, show evidence of paludification and transition to tundra vegetation between 10000 and 8500 ${ }^{14} \mathrm{C}$ years BP (Mann et al., 2001, 2002).

Bison are not inhabitants of wet or moist tundra ecosystems, and north of the Brooks Range, the dry graminoidbased systems upon which they normally depend were replaced by paludified tundra systems shortly after 10300 ${ }^{14} \mathrm{C}$ years BP. Paludification was a slower and less complete process farther south and east, where the climate remained more continental through the late glacial and Holocene. The interior's warmer, drier climate, combined with its greater topographic variation and loess influx, probably facilitated the development of a variety of open woodland ecosystems (e.g., parkland and savannah) with greater habitat heterogeneity and sufficient pockets of grassland communities to support bison. This hypothesis is supported by an extensive pollen data set from the interior and increased presence of the elk, a mixed grazerbrowser that inhabits mostly parklands; elk were rare or absent from the Mammoth Steppe (Guthrie, 2006). Paludification did gradually increase in the interior through the Holocene (Hu and Brubaker, 1996), though not as abruptly or extensively as on the North Slope, and habitat and numbers of both bison and elk declined commensurately until their ultimate demise in late prehistoric times (Guthrie, 2006).

\section{ACKNOWLEDGEMENTS}

We thank Roger Colten at the Yale Peabody Museum for arranging the loan of the Kangiguksuk specimens. Comments from Dan Odess and three anonymous reviewers improved the manuscript. Ted Birkedal, Grant Spearman, and Dale Vinson provided useful information concerning the Lakeside site context. Beth Shapiro performed the genetic analyses of the Lakeside metatarsal, in conjunction with her study of ancient bison genetics. The sequence she derived showed that it came from a moose, not a bison, and we thank her for that work. Andrea Krumhardt provided excellent laboratory assistance with collagen extractions. Radiocarbon dating of the Lakeside bone was supported by Gates of the Arctic National Park and Preserve, and National Science Foundation grant 0227962 paid for the analysis of the Kangiguksuk specimens. The Bureau of Land Management, Northern Field Office, Fairbanks, has provided extensive support for fieldwork in north-central Alaska and for radiocarbon dating of specimens cited in this paper. Michael Kunz has played a key role orchestrating that work and has provided many stimulating discussions of bison and humans in Beringia.

\section{REFERENCES}

ANDERSON, P.M., and BRUBAKER, L.B. 1994. Vegetation history of northcentral Alaska: A mapped summary of lateQuaternary pollen data. Quaternary Science Reviews 13:7192.

BAMFORTH, D.B. 1988. Ecology and human organization on the Great Plains. New York: Plenum Press.

BEVER, M.R. 2006. Too little, too late? The radiocarbon chronology of Alaska and the peopling of the New World. American Antiquity 71(4):595-620.

FORD, J.A. 1959. Eskimo prehistory in the vicinity of Point Barrow, Alaska. Anthropological Papers of the American Museum of Natural History 47. New York: American Museum of Natural History.

FRISON, G.C. 1991. Prehistoric hunters of the High Plains, 2nd ed. San Diego: Academic Press.

GIDDINGS, J.L. 1952. The Arctic Woodland culture of the Kobuk River. Philadelphia: University Museum, University of Pennsylvania.

GUTHRIE, R.D. 1968. Paleoecology of the large-mammal community in interior Alaska during the late Pleistocene. The American Midland Naturalist 79(2):346-363.

- 1990. Frozen fauna of the mammoth steppe: The story of Blue Babe. Chicago: University of Chicago Press.

- 2006. New carbon dates link climatic change with human colonization and Pleistocene extinctions. Nature 441:207-209.

HALL, E.S., Jr. 1966. Kangiguksuk: A cultural reconstruction of a sixteenth century Eskimo site in northern Alaska. PhD dissertation, Department of Anthropology, Yale University.

. 1971. Kangiguksuk: A cultural reconstruction of a sixteenth century Eskimo site in northern Alaska. Arctic Anthropology 8(1):1-101.

HARINGTON, C.R. 2003. Annotated bibliography of Quaternary vertebrates of northern North America with radiocarbon dates. Toronto: University of Toronto Press.

HU, F.S., and BRUBAKER, L.B. 1996. Boreal ecosystem development in the northwestern Alaska Range since 11,000 yr B.P. Quaternary Research 45:188-201.

KUNZ, M.L., MANN, D.H., MATHEUS, P.E., and GROVES, P. 1999. The life and times of Paleoindians in Arctic Alaska. Arctic Research of the United States 13:33-39.

LARSEN, H., and RAINEY, F. 1948. Ipiutak and the Arctic whale hunting culture. Anthropological Papers of the American 
Museum of Natural History 42. New York: American Museum of Natural History.

MANN, D. H., REANIER, R.E., PETEET, D.M., KUNZ, M.L., and JOHNSON, M. 2001. Environmental change and Arctic Paleoindians. Arctic Anthropology 38(2):119-138.

MANN, D.H., PETEET, D.M., REANIER, R.E., and KUNZ, M.L. 2002. Responses of an Arctic landscape to Lateglacial and early Holocene climatic changes: The importance of moisture. Quaternary Science Reviews 21:997-1021.

MATHEUS, P.E. 1995. Diet and co-ecology of Pleistocene shortfaced bears and brown bears in Eastern Beringia. Quaternary Research 44:447-453.

- 2003. A late Quaternary mammal record from northern Alaska. Geological Society of America Annual Meeting Abstracts with Programs 35:546.

MATHEUS, P., KUNZ, M., and GUTHRIE, R.D. 2003. Using frequency distributions of radiocarbon dates to detect relative changes in Pleistocene mammal populations: A test case from northern Alaska. In: Third International Mammoth Conference Program and Abstracts. Occasional Papers in Earth Sciences 5. Whitehorse: Paleontology Program, Government of the Yukon.

OSWALD, W.W., BRUBAKER, L.B., and ANDERSON, P.M. 1999. Late Quaternary vegetation history of the Howard Pass area, northwestern Alaska. Canadian Journal of Botany 77: $570-581$.

SALEEBY, B.M. 2002. Out of place bones: Beyond the study of prehistoric subsistence. Arctic Research of the United States 16:55-62.
SHAPIRO, B., DRUMMOND, A.J., RAMBAUT, A., WILSON, M., SHER, A., PYBUS, O.G., GILBERT, M.T.P., BARNES, I., BINLADEN, J., WILLERSLEV, E., HANSEN A., BARYSHNIKOV, G.F., BURNS, J., DAVYDOV, S., DRIVER, J., GUBIN, S.V., HARINGTON, C.R., KEDDIE, G., KOSINTSEV, P., KUNZ, M.L., MARTIN, L.D., STEPHENSON, R., STORER, J., TEDFORD, R., VOROBIEV, A., ZIMOV, S., and COOPER, A. 2004. Rise and fall of the Beringian steppe bison. Science 306: $1561-1565$.

SPEARMAN, G. 1991. Killik and Nigu River archaeological and ethnohistoric survey. Unpubl. report. Available at Gates of the Arctic National Park and Preserve, 4175 Geist Rd., Fairbanks, Alaska 99701.

STAFFORD, T.W., Jr., BRENDEL, K., and DUHAMEL, R.C. 1988. Radiocarbon ${ }^{13} \mathrm{C}$ and ${ }^{15} \mathrm{~N}$ analysis of fossil bone: Removal of humates with XAD-2 Resin. Geochimica et Cosmochimica Acta 52:2257-2267.

STANFORD, D.J. 1976. The Walakpa site, Alaska: Its place in Birnirk and Thule cultures. Smithsonian Contributions to Anthropology 20. Washington, D.C.: Smithsonian Institution Press.

STEPHENSON, R.O., GERLACH, S.C., GUTHRIE, R.D., HARINGTON, C.R., MILLS, R.O., and HARE, G. 2001. Wood bison in late Holocene Alaska and adjacent Canada: Paleontological, archaeological and historical records. In: Gerlach, S.C., and Murray, M.S., eds. People and wildlife in northern North America: Essays in honor of R. Dale Guthrie. British Archaeological Reports, International Series 944. Oxford: Archaeopress. 124-158. 